\title{
Studi Komparatif Penanganan Pandemi di Taiwan: SARS, HINI, dan COVID-19
}

\author{
Ardila Putri', Silvia D. Anggraeni ${ }^{2}$, Rika Isnarti ${ }^{3}$, dan Nisrina N. Khairunisa ${ }^{4}$ \\ Universitas Pertamina
}

\begin{abstract}
Taiwan is considered as one of the countries that has successfully controlled the spread of COVID-19. Taiwan stated that their success in controlling the spread of COVID-19 was inseparable from their experience in dealing with SARS in 2003. This paper aims to compare Taiwan's response to SARS 2003, H1N1 in 2009, and COVID-19. By comparing Taiwan's response, this article detailing the transformation of Taiwan's policy in every pandemic and analyze the lesson learn for developing countries, including Indonesia, in dealing with a pandemic of communicable diseases in the future. In 2003 Taiwan had made some negligence as developing countries did when the outbreak of COVID-19. By looking at the transformation of Taiwan's policy, we can draw conclusions about the steps that developing countries can take in the future in controlling the spread of infectious diseases. This paper uses the tradition of empiricism with an indirect observation mechanism through the study of literature to describe the transformation of Taiwan's policies and analyze the lessons that can be taken by developing countries. The learning relates to communicable disease monitoring, border quarantine, communicable disease reporting, response planning, contact tracing, laboratory capacity building, public health education, open and transparent information.
\end{abstract}

Keywords: Taiwan, SARS 2003, H1N1, COVID-19, Health Politics

\section{PENDAHULUAN}

Pada tahun 2020 ini, dunia kembali menghadapi pandemi global. Dilaporkan pada 31

Desember 2019, terjadi penyebaran wabah penyakit pernapasan di Wuhan, Provinsi Hubei, Tiongkok, yang disebabkan oleh virus korona baru dan kemudian dikenal dengan nama Coronavirus Disease 2019 (COVID-19). COVID-19 menyebar dengan cepat ke berbagai wilayah di Tiongkok dan berbagai negara di dunia. Penyebaran yang makin meluas menyebabkan World Health Organization (WHO) mengumumkan bahwa COVID-19 menjadi pandemi global. Hingga akhir tahun 2020, virus ini masih menyebar luas dan masih memberikan efek buruk terhadap hubungan internasional baik dari segi sosial, ekonomi, maupun budaya masyarakat global (Cheng, 2020)

Di tengah krisis kesehatan yang saat ini menimpa berbagai negara di dunia, Taiwan tergolong sebagai salah satu negara yang sukses dalam mengendalikan penyebaran COVID19 di negaranya. Taiwan merupakan salah satu daerah yang sangat dekat dengan China sebagai pusat penyebaran COVID-19. Negara yang belum banyak diakui sebagai negara merdeka ini memiliki intensitas hubungan yang sangat kuat dengan China. Lalu lintas barang, 
jasa, dan orang diantara kedua negara sangat intens. Walaupun begitu, penyebaran COVID19 di Taiwan jauh lebih rendah dibandingkan daerah lain yang juga memiliki hubungan dekat dengan China. Hingga Desember 2020, kasus terkonfirmasi positif kurang dari 800 kasus dan kebanyakan dari kasus tersebut merupakan kasus impor. Taiwan juga tidak pernah melakukan lockdown selama pandemi COVID-19 ini (Lin, 2020).

Dalam beberapa publikasi baik itu yang disampaikan oleh para ahli pandemi dalam artikel-artikel ilmiah, para politisi dan pemerintah dalam setiap laporan, juga para jurnalis dalam berbagai laporan berita internasional, disampaikan bahwa keberhasilan Taiwan dalam mengendalikan penyebaran COVID-19 tidak terlepas dari pengalaman mereka dalam menghadapi beberapa pandemi sebelumnya, salah satu yang terbesar adalah kasus SARS 2003. Pada tahun 2003, Taiwan menghadapi SARS dikarenakan kurangnya persiapan yang dilakukan oleh negara tersebut dalam menghadapi pandemi. Taiwan menjadi salah satu negara dengan kasus SARS terbanyak di tahun 2003 dan korban terbesar dari kasus ini adalah para pekerja medis. Berangkat dari pengalaman inilah kemudian Taiwan melakukan beberapa reformasi kebijakan kesehatan terutama dalam penanggulangan penyakit menular. Hingga akhirnya kesiapan negara ini teruji dengan keberhasilannya menghadapi beberapa pandemi paska tahun 2003 (Yen, 2014).

Melihat keberhasilan Taiwan dan fenomena transformasi kebijakan yang dilakukan oleh negara tersebut, maka tulisan ini bertujuan untuk membandingkan respons Taiwan terhadap wabah Severe Acute Respiratory Syndrome (SARS) tahun 2003, H1N1 di tahun 2009, dan COVID-19. Dengan membandingkan respons Taiwan tersebut, tulisan ini melihat transformasi kebijakan Taiwan di setiap pandemi dan mengambil pembelajaran bagi negara berkembang termasuk Indonesia dalam menangani pandemi penyakit menular di masa mendatang. Pada tahun 2003, Taiwan melakukan beberapa keteledoran seperti yang dilakukan oleh negara berkembang saat merebaknya COVID-19. Dengan melihat transformasi kebijakan Taiwan, tulisan ini menarik kesimpulan langkah-langkah yang bisa dilakukan oleh negara berkembang kedepannya dalam mengendalikan penyebaran penyakit menular.

Penelitian-penelitian terkait respons negara terhadap pandemi sangat perlu dilakukan oleh para ilmuwan dan kelompok epistemik Indonesia untuk meningkatkan diskursus mengenai politik pandemi. Dengan semakin banyaknya laporan ilmiah terkait politik pandemi, maka Indonesia akan memiliki banyak sumber kredibel yang dapat dijadikan acuan untuk transformasi kebijakan kesehatan yang lebih baik di masa depan. Oleh karena itu, 
penulis percaya salah satu signifikansi yang diberikan oleh tulisan ini adalah untuk memperkaya kajian-kajian terkait politik pandemi yang dalam hal ini adalah pembelajaran yang dapat diambil dari kesuksesan Taiwan dalam menghadapi pandemi.

\section{METODE PENELITIAN}

Tulisan ini merupakan penelitian yang menggunakan tradisi empirisme yaitu penelitian dengan tujuan untuk menjelaskan sebuah fenomena berdasarkan hasil observasi. Observasi yang dilakukan adalah observasi tidak langsung dimana peneliti memanfaatkan data sekunder dari penelitian-penelitian terdahulu. Data ini dikumpulkan dan dianalisis menggunakan pendekatan kualitatif dengan tujuan untuk mendapatkan pemahaman mendalam mengenai fenomena yang bersangkutan melalui interpretasi terhadap data yang dikumpulkan.

Pengumpulan data dilakukan melalui penelusuran di internet terutama melalui google scholars dengan kata kunci diantaranya: SARS 2003, SARS Outbreak in Taiwan, Lesson Learn from SARS Outbreak, Taiwan Responsds to SARS and H1N1, Covid-19 in Taiwan, Taiwan Health Policy, Taiwan Model in Covid-19 Prevention. Selain itu, penulis juga mendapatkan data yang cukup lengkap dari laman kementerian luar negeri Taiwan. Sumber lain yang menjadi rujukan utama dari tulisan ini adalah dari transkrip webinar yang diadakan oleh Universitas Johns Hopkins dengan narasumber wakil presiden Taiwan Chen Chien-Jen. Wakil presiden Chen merupakan ahli pandemi dan menjabat sebagai Menteri Kesehatan Taiwan saat pandemi SARS 2003 juga saat reformasi kebijakan kesehatan publik Taiwan di tahun 2004 dan 2005, sehingga penjelasan beliau tentang respons Taiwan menghadapi pandemi adalah sumber yang sangat dapat dipercaya sebagai salah satu sumber data primer dalam tulisan ini.

Penulis menggunakan mekanisme triangulasi data untuk mengukur keabsahan informasi yang dikumpulkan melalui studi literatur. Salah satu metode triangulasi yang dilakukan adalah dengan memeriksa informasi yang didapatkan dari beberapa sumber utama (artikel ilmiah) dengan beberapa berita yang didapatkan dari penelusuran internet. Setelah pemeriksaan keabsahan data, maka penulis menyusun data-data tersebut sesuai dengan data yang sudah disampaikan dalam artikel ilmiah yang ada. Setelah mendapatkan data dari studi literatur, penulis menyusun tulisan ini dengan terlebih dahulu menjelaskan tentang fenomena pandemi SARS pada tahun 2003.

Penjelasan ini pada akhirnya memberikan gambaran kepada pembaca bagaimana pada masa ini Taiwan belum siap dalam menghadapi pandemi. Kemudian tulisan ini menjelaskan tentang transformasi kebijakan Taiwan terkait pengendalian penyakit menular 
dan melihat realisasi pelaksanaan mekanisme kebijakan ini pada pandemi H1N1 di tahun 2009. Kemudian tulisan ini dilanjutkan dengan meninjau kondisi Taiwan dalam penanganan COVID-19. Di bagian akhir, tulisan ini menganalisa poin-poin penting yang bisa diambil sebagai pembelajaran bagi negara berkembang termasuk Indonesia untuk melakukan transformasi kebijakan pengendalian penyakit menular di masa depan.

\section{HASIL DAN PEMBAHASAN SARS 2003 di Taiwan}

Epidemi SARS tahun 2003 di Taiwan dapat dibagi dalam 3 fase. Fase pertama adalah saat awal kasus SARS mulai masuk ke Taiwan (sebelum 20 April 2003); dilanjutkan oleh fase kedua pada 21 April hingga 20 Mei 2003 yang merupakan puncak penyebaran; serta fase terakhir pada 21 Mei hingga 5 Juli 2003. Kasus SARS pertama yang terdeteksi di Taiwan adalah pada seorang pebisnis yang pulang dari China pada 25 Februari 2003. Kasus ini baru teridentifikasi pada 14 Maret 2003. Dari tanggal 14 Maret hingga 21 April 2003, Taiwan melaporkan terdapat 28 kasus SARS. Pada fase awal ini, Taiwan mampu menanggulangi penyebaran virus dengan baik. semua kasus pada fase awal ini merupakan kasus yang diimpor dari Guandong, Beijing, dan Fujiang, dimana semuanya adalah wilayah dari China. Langkahlangkah yang dilakukan oleh kementerian kesehatan Taiwan saat itu adalah membentuk dewan penasehat terkait SARS, pelatihan pengendalian infeksi, pelacakan kontak dan karantina, juga pengawasan bandara serta perbatasan. Karena kesuksesan Taiwan dalam mengendalikan SARS di fase pertama ini, pada awal April 2003 WHO mengganti status Taiwan dari yang awalnya "area terpengaruh" menjadi "area dengan transmisi lokal terbatas". Keberhasilan di tahap pertama ini membuat Taiwan melonggarkan kewaspadaannya dan mempolitisasi isu ini dengan menyatakan Taiwan berhasil menanggulangi SARS sebagai laporan mereka terhadap WHO. Longgarnya kewaspadaan ini menyebabkan Taiwan mengalami gelombang kedua penyebaran SARS (Su, 2008).

Gelombang SARS kedua dimulai pada 21 April 2003, dimana terjadi penyebaran virus di salah satu rumah sakit di Taiwan. Terdapat 30 kemungkinan dan 50 dugaan kasus SARS pada waktu tersebut. Kasus ini bermula dari salah satu pekerja kebersihan rumah sakit yang terjangkit wabah SARS tapi belum terdeteksi. Pekerja ini berinteraksi cukup intens dengan pasien, staf, dan pengunjung rumah sakit. Pada 22 April 2003, dilaporkan bahwa salah satu rumah sakit di Taipei menjadi klaster penyebaran virus SARS. 61 pekerja medis dikarantina beserta dengan beberapa staf rumah sakit lainnya. Dalam waktu 24 jam, penderita SARS bertambah 10 orang diluar pasien yang telah dikarantina. Pada 23 April ditemukan bahwa 
mayoritas kasus berasal dari ruang gawat darurat dan dari 6 lantai yang berbeda di rumah sakit tersebut. Dengan banyaknya pasien dari beberapa lokasi dalam satu rumah sakit ini, maka disimpulkan bahwa SARS telah menyebar di rumah sakit tersebut dan telah menyebar ke tempat lain karena interaksi orang-orang yang pernah berada di rumah sakit tersebut setidaknya seminggu sebelum rumah sakit tersebut diketahui sebagai klaster penyebaran SARS (CDC, 2003).

Awalnya pihak rumah sakit enggan mengakui bahwa telah terjadi penyebaran SARS di tempat mereka sehingga respons rumah sakit di awal merebaknya kasus ini sangatlah lamban. Rumah sakit mulai bertindak cepat setelah diintervensi pihak luar (Su, 2008). Pada 23 April 2003, kementerian kesehatan menunjuk gugus tugas untuk mengurus permasalahan penyebaran SARS di rumah sakit tersebut. Sehari setelahnya, rumah sakit tersebut langsung dikarantina secara keseluruhan, dimana staf, pengunjung, dan pasien tidak diizinkan keluar. Bagi pasien dan pengunjung yang sudah tidak berada di rumah sakit tapi berada disana semenjak 9 April 2003, diwajibkan untuk melakukan karantina di rumah masing-masing. Pasien yang terdekteksi mengidap SARS langsung ditempatkan di 2 lantai rumah sakit yang dikhususkan untuk pasien positif SARS. Alat pelindung diri langsung didistribusikan dan petugas medis diawasi dengan ketat. Walaupun begitu, kasus SARS terus meningkat dari hari ke hari. Sejak tanggal 29 April hingga 8 Mei tercatat ada 81 orang pasien positif SARS yang dipindahkan ke 15 rumah sakit di Taipei. 200 orang lainnya yang diduga terkena SARS tapi hasilnya negatif dikarantina secara mandiri di rumah masing-masing atau dipindahkan ke rumah sakit lain. Hingga 22 Mei, terdapat total 137 kasus SARS yang diduga berasal dari penyebaran di klaster Rumah Sakit Taipei Municipal, dimana 45 orang (37\%) diantaranya merupakan petugas medis, dan 26 orang (19\%) meninggal dunia (CDC, 2003).

Rumah sakit Taipei Municipal Hoping Hospital sebagai klaster pertama penyebaran SARS, ternyata juga menimbulkan efek domino terhadap 8 rumah sakit lainnya. Data awal menunjukkan bahwa mayoritas dari klaster ini berasal dari pasien yang terjangkit atau teridentifikasi SARS, kemudian dipulangkan atau dipindahkan ke fasilitas layanan kesehatan lainnya. Hal ini menyebabkan SARS menyebar dengan cepat ke berbagai wilayah di seluruh Taiwan termasuk beberapa universitas dan rumah sakit. 4 dari 8 rumah sakit ini telah menghentikan layanan darurat dan layanan rutinnya serta fokus untuk mengobati pasien SARS. Selain persebaran di Rumah Sakit dan Universitas, penyebaran SARS secara sporadis di tengah masyarakat juga banyak ditemukan. Hal ini menyebabkan Taiwan menjadi 
episentrum penyebaran SARS terbanyak ketiga di dunia, setelah Daratan China dan Hongkong (Chen, 2005)

Menyadari bahwa meluasnya penyebaran SARS disebabkan karena kebijakan rumah sakit yang tidak transparan, maka pemerintah memberikan sanksi kepada pihak rumah sakit dan menuntut agar seluruh rumah sakit transparan dalam menginformasikan kasus SARS di rumah sakitnya. Hal ini pada akhirnya membuat pelaporan kasus baru menjadi cepat dan banyak. Kondisi ini pada akhirnya membuat beberapa laboratorium dan rumah sakit ditutup di akhir Mei karena menjadi pusat penyebaran infeksi. Maraknya kasus SARS menimbulkan kepanikan di kalangan masyarakat apalagi dengan banyaknya penyebaran informasi palsu. Kepanikan yang berujung pada kelangkaan masker dan menyebabkan Taiwan berada dalam suasana yang sangat kacau (Yen, 2014).

Kementerian Kesehatan Taiwan memutuskan untuk mengatur ulang mekanisme respons mereka terhadap wabah. Kemenkes menunjuk kepala gugus tugas dan mendirikan pusat operasi darurat (Emergency operations center). Upaya utama pemerintah saat itu adalah dengan menunjuk beberapa rumah sakit untuk secara khusus menangani pasien SARS. Sekitar 100 klinik juga didirikan untuk mengidentifikasi pasien yang diduga SARS dan meminimalisir penyebaran virus di Unit Gawat Darurat (UGD). Pemerintah juga mendirikan 1000 ruang isolasi serta mengubah tempat perkemahan dan fasilitas militer untuk mengakomodasi penduduk yang dikarantina. Isolasi mandiri di rumah dilakukan dengan mekanisme kamera berbasis web. Pengecekan demam pada semua pasien, petugas kesehatan, dan pengunjung telah diwajibkan di semua fasilitas layanan kesehatan. Kemenkes juga mengembangkan kurikulum untuk melatih tim pengendalian penyakit menular serta terus mengedukasi dan memantau para pertugas kesehatan. Pemerintah juga mengeluarkan Standar Operasional Prosedur (SOP) terkait manajemen dan pengendalian kluster SARS nosokomial (SARS yang menyebar di rumah sakit). Berkat berbagai upaya yang dilakukan oleh pemerintah, dan juga atas dukungan tim WHO yang datang ke Taiwan pada 4 Mei 2003, akhirnya Taiwan berhasil mengendalikan penyebaran SARS. Ini dianggap sebagai fase terakhir pandemi SARS 2003 di Taiwan (Su, 2008).

Menurut para ahli, upaya awal penanggulangan SARS 2003 di Taiwan tidak berjalan dengan baik terutama pada fase kedua disebabkan oleh beberapa alasan yaitu: kurangnya koordinasi antar organisasi, tidak jelasnya rantai komando, tidak efisiensinya alokasi sumber daya, dan arus informasi yang tidak terkendali. Hal ini akhirnya mengakibatkan 347 kematian dimana 30\% dari korban merupakan pekerja kesehatan. Berangkat dari pengalaman inilah 
kemudian Taiwan melakukan beberapa reformasi kebijakan kesehatan terutama di bagian penanggulangan penyakit menular.

\section{Reformasi Kebijakan Taiwan Paska SARS 2003}

Paska epidemi SARS 2003, Taiwan mengubah strategi pengendalian penularan penyakit di rumah sakit. Strategi tersebut di antaranya: memperbaiki sistem pengawasan serta meningkatkan sistem dukungan dan pendidikan terkait penanganan penyakit menular. Inspeksi tahunan dan kunjungan lapangan juga diterapkan untuk memastikan kesiapan rumah sakit dalam penanganan penyakit menular. Pemerintah membiayai vaksin influenza tahunan untuk melindungi petugas medis dari infeksi nosokomial dan penyakit menular. Program vaksinasi mulai dimasukkan dalam salah satu syarat akreditasi dan proses inspeksi oleh badan yang membawahi pengendalian penyakit menular yang dimulai pada tahun 2003 . Semenjak diterapkan, rata-rata tingkat partisipasi petugas kesehatan dalam vaksinasi tahunan influenza adalah sekitar 90\%. Lebih lanjut, strategi untuk menjaga kebersihan tangan telah memiliki dampak langsung pada pengurangan infeksi nosokomial di Taiwan (Yen, 2014).

Taiwan juga mengembangkan pendekatan sistematik dan terintegrasi untuk penanggulangan terhadap penyebaran penyakit menular berdasarkan Sistem Manajemen Insiden (Incident Management System/IMS) dan Enam Sigma. IMS merupakan rantai komando dan sistem kontrol yang terdiri dari empat komponen: tindakan, perencanaan, pembiayaan, dan dukungan logistik. IMS dapat diterapkan pada skala bencana apapun baik kecil maupun besar, dan memungkinkan institusi pemerintah untuk mengoordinasikan respons lintas bidang kelembagaan. 'Enam Sigma' adalah prinsip manajemen proses yang berasal dari sistem teknik industri dan manajemen. Pendekatan ini menyederhanakan proses rumit menjadi langkah-langkah kecil yang lebih mudah dikelola dan dapat lebih mudah dianalisis untuk menangani permasalahan dan mengurangi risiko. Taiwan menerapkan prinsip-prinsip IMS dan Six Sigma untuk meningkatkan upayanya di 3 bidang utama yaitu pengaturan arus masuk pasien, Jaringan Pengendalian Penyakit Menular, dan Manajemen Krisis (Yen, 2014).

Saat epidemi SARS 2003, Taiwan kehilangan banyak tenaga medisnya sehingga kebijakan untuk melindungi tenaga medis menjadi prioritas negara tersebut ke depannya. Salah satu transformasi kebijakan yang dihasilkan adalah mengenai pengaturan arus masuk pasien yang diduga terinfeksi SARS. Terdapat 4 langkah yang dilakukan yaitu; pertama memastikan status atau kondisi pasien sebelum pasien masuk ke rumah sakit (melakukan pemeriksaan awal); kedua, menempatkan pasien yang positif SARS di ruang isolasi khusus; ketiga, menempatkan tenaga medis di ruang isolasi khusus sebelum mereka bertugas; 
keempat, memasang alat sanitasi di berbagai tempat terutama untuk menyediakan alkohol $75 \%$ dan sarung tangan steril bagi tenaga medis dan pasien. Yen et al, menganggap bahwa pengaturan arus masuk pasien ini adalah langkah utama yang harus diterapkan di rumah sakit agar bisa melindungi tenaga medis dan di saat bersamaan dapat mengurangi penyebaran penyakit menular (Yen, 2014).

Belajar dari pengalaman SARS sebelumnya, dengan menggunakan prinsip-prinsip IMS, Taiwan mengintegrasikan sistem medis dan kesehatan masyarakat dengan mendirikan 6 jaringan pengendalian penyakit menular (Communicable Disease Control Networks/CDCNs) di seluruh Taiwan. Para ahli dari rumah sakit, unit pengontrol infeksi/penyakit menular dan kesehatan masyarakat, juga beberapa unit di kementerian kesehatan pusat dan daerah direkrut untuk bekerja di bawah koordinasi seorang direktur medis yang berperan sebagai kepala sistem manajemen insiden (IMS). Pembangunan model CDCNs ini ditujukan agar saat terjadinya peristiwa darurat, perintah dan juga informasi dapat dengan mudah disampaikan dan dikoodinasikan baik itu secara pertemuan tatap muka, konferensi video, maupun konferensi telepon. Untuk memfasilitasi perencanaan dan tindakan medis dalam kesiapsiagaan menghadapi pandemi, CDCN berbagi sumber daya manusia, dukungan logistik, informasi pengawasan, informasi lonjakan kasus, serta informasi tentang rumah sakit isolasi khusus. CDCN secara berkala juga melakukan latihan untuk menguji efektivitas koordinasi antar organisasi dalam menghadapi peristiwa-peristiwa darurat terutama kesiapsiagaan dalam menghadapi pandemi penyakit menular (Yen, 2014).

Dalam hal manajemen krisis, Taiwan telah mengembangkan sebuah sistem fase peringatan yang sejalan dengan sistem WHO. Sistem pemberitahuan risiko pandemi lokal di Taiwan dibagi menjadi empat fase peringatan. Fase tersebut meliputi $0, A, B$, dan $C$ dan sejalan dengan petunjuk WHO tentang fase pengendalian penyebaran penyakit menular. Fase 0 juga disebut oleh WHO dengan fase "interpandemic" dan Fase A disebut dengan fase “alert". Pada fase 0, rata-rata kasus penularan penyakit secara global masih sangat rendah. Fase A adalah saat kondisi rata-rata kasus penularan penyakit secara global mulai meningkat. Kemudian jika rata-rata kasus penularan secara global terus menerus naik, maka Taiwan akan menetapkan fase B dan C. Belajar dari pengalaman penyebaran SARS 2003, dalam melakukan transformasi kebijakannya, Taiwan banyak berfokus untuk memperbaiki berbagai kebijakan pada fase B dan C karena ini berhubungan dengan upaya pencegahan penyebaran di rumah sakit dan menghindari korban tenaga medis (Yen, 2014). 
Fase B dinyatakan ketika sejumlah kasus penularan terbatas dari manusia ke manusia di Taiwan telah diidentifikasi. Strategi respons selama fase ini adalah meningkatkan semua upaya epidemologis, diantaranya: memobilisasi sumber daya kesehatan masyarakat, dan mengembangkan sumber daya yang tersedia untuk membatasi penyebaran penyakit dengan mengkarantina kontak dan mengisolasi orang sakit di rumah sakit dengan unit isolasi khusus yang dirancang untuk penyakit menular. Juga melakukan upaya lain terutama upaya peningkatan jarak sosial seperti pembatasan penggunaan angkutan umum masal. Fase $\mathrm{C}$ dinyatakan ketika sejumlah kasus transmisi lokal/komunitas telah diidentifikasi di Taiwan. Dalam fase ini akan banyak masyarakat berobat ke rumah sakit dan akan menyebabkan meningkatnya kebutuhan akan fasilitas medis. Strategi yang akan diterapkan dalam fase ini adalah transisi ke mode respons bencana untuk mengurangi dampak buruk dari penyebaran penyakit menular, menjaga ketertiban sosial, dan mendukung sistem layanan kesehatan. Dan terakhir, paska pandemi (WHO menyebutnya dengan 'fase transisi'), Taiwan berfokus pada pemulihan krisis dan menarik pembelajaran untuk memperbaiki dan meningkatkan respons pandemi sebagai persiapan menghadapi wabah di masa depan (Yen, 2014).

Selain strategi respons pada empat fase yang berpedoman pada petunjuk WHO ini, Taiwan juga mengembangkan upaya lain yang berfokus pada pengawasan dan penanganan pada fase lonjakan jika terjadi pelonjakan jumlah pasien yang tertular virus. Di antara berbagai upaya pengawasan penyakit menular, pengawasan terhadap sindrom pernapasan dianggap sebagai upaya paling efektif. Walaupun begitu, dalam kasus SARS 203, Taiwan menemukan bahwa sistem ini tidak berjalan efektif dikarenakan lambatnya pelaporan kasus. Untuk menanggulangi masalah ini di masa depan, maka pemerintah Taiwan mengubah sistem pengawasan yang awalnya bersifat pengawasan dan pelaporan manual menjadi pengawasan dan pelaporan secara otomatis terkomputerasi memanfaatkan perkembangan teknologi dan informasi. Pemerintah merancang sistem pengawasan dengan prinsip-prinsip berikut: pertama, sistem pemantauan terintegrasi yang secara otomatis dapat mengumpulkan data dari IGD rumah sakit secara tepat waktu dan fleksibel; kedua, algoritma yang memungkinkan deteksi dini wabah dengan menganalisis data yang telah dikumpulkan; dan sistem situs web yang memudahkan perawat untuk memasukkan berbagai data secara cepat dan mempermudah proses analisis epidemi. Pemerintah Taiwan mengembangkan analisis dan kebijakannya dengan memanfaatkan analisa big data yang ditunjang dengan pengembangan sistem informasi yang kuat. Selain itu, pemerintah juga menekankan pentingnya pasien maupun tenaga medis untuk mengetahui sejarah TOCC (Travel/perjalanan, 
Occupation/pekerjaan, Contact/kontak, Clustering/wilayah tempat tinggal dan beraktivitas) pasien (Yen, 2014).

Kebijakan lain yang tak kalah pentingnya selain pemantauan melalui big data adalah terkait dengan persiapan manajemen krisis saat terjadinya lonjakan kasus penyakit menular. Saat terjadi lonjakan kasus, walaupun pemerintah telah menyiapkan stok obat-obatan dan rumah sakit yang khusus menangani penyakit menular, akan ada kemungkinan hal itu tidak akan cukup. Oleh karena itu pemerintah juga menyiapkan strategi lain untuk menyikapi jika terjadi lonjakan kasus yaitu dengan mempersiapkan sekolah sebagai tempat alternatif untuk mengkarantina pasien jika seandainya kapasitas rumah sakit tidak mampu lagi menampung pasien. Sekolah dianggap sebagai tempat karantina alternatif karena tata letak sekolah terutama adanya kelas-kelas dapat dengan mudah diubah menjadi tempat karantina dan isolasi. Sedangkan lapangan terbuka yang biasanya ada di lingkungan sekolah dapat dimanfaatkan sebagai tempat untuk menjalankan tes bagi pasien dengan skala banyak (Yen, 2014).

Selain kebijakan-kebijakan yang berkaitan dengan teknis penanganan wabah, Taiwan juga berkosentrasi untuk mempersiapkan institusionalisasi pengendalian wabah. Langkah Taiwan dalam mempersiapkan kebijakan publiknya ini adalah salah satu kunci besar dalam mempermudah koordinasi negara yang tidak dilibatkan dalam pertemuan tahunan World Health Assembly dibawah WHO ini. Pada tahun 2004, Taiwan merevisi Undang-Undang Pengendalian Penyakit Menular. UU ini merupakan salah satu pencapaian terbesar Taiwan dalam kebijakan kesehatan masyarakat karena menjadi negara pertama yang mengatur tentang pendirian Pusat Komando Epidemi (Central Epidemic Commend Center/CECC) jika terjadi pandemi global. UU ini juga mengatur tentang pendirian Pusat Komando Kesehatan Nasional (National Health Command Center/NHCC) sebagai sistem data terpadu yang bertugas menyediakan informasi dan data tentang penyakit menular bagi pemerintah pusat, pemerintah daerah, dan pihak berkepentingan lainnya. Pusat Komando ini didukung dengan Teknologi Informasi yang sangat canggih yang terus selalu dikembangkan oleh Taiwan (Su, 2008).

Selain institusionalisasi penanganan penyakit menular melalui UU dan pendirian lembaga khusus, Taiwan juga terus melakukan reformasi dalam sistem perlindungan kesehatan mereka. Sistem Asuransi Nasional Satu Pintu (National Health Insurance/NHI) yang telah diterapkan di Taiwan semenjak tahun 1995 dan mencakup 99\% populasi masyarakat Taiwan terus di reformasi. Pemerintah berinvestasi besar-besaran untuk mendukung 
pengembangan Teknologi Informasi sehingga penyelenggaraan Sistem Asuransi Nasional bisa berjalan dengan efektif dan efisien. Pada tahun 2003 pemerintah Taiwan meluncurkan kartu NHI elektronik untuk menyimpan data masing-masing pasien sehingga memudahkan dalam mengumpulkan informasi data terpadu untuk dianalisa dengan cepat melalui analisa big data (Putri, 2020).

\section{H1N1 Influenza dan Uji Coba Kesiapan Taiwan dalam Pengendalian Penyakit Menular}

Pada April 2009, virus H1N1 teridentifikasi di Meksiko dan menyebar dengan cepat ke berbagai daerah di dunia dalam kurun waktu kurang dari 6 minggu. Pada 20 Mei 2009, Taiwan mengidentifikasi penyebaran virus ini daerah mereka untuk pertama kalinya dan menjadi awal penerapan uji coba berbagai mekanisme pengendalian penyebaran penyakit menular yang telah disusun Taiwan paska pengalaman buruk mereka dalam penanganan SARS pada tahun 2003. Taiwan mengaktifkan Rumah Sakit yang telah ditetapkan sebagai Rumah Sakit isolasi khusus untuk menangani pasien H1N1. Respons awal Taiwan bersifat penghambatan penyebaran penyakit yang berfokus pada menemukan kasus melalui investigasi epidemologi aktif dan pelacakan kontak juga karantina rumah. Respons awal ini berhasil mengendalikan penyebaran H1N1 karena berhasil menghindarkan Taiwan dari penyebaran lokal atau komunitas.

Setelah WHO mengumumkan H1N1 sebagai pandemi global, maka Taiwan mengubah strateginya dari penghambatan menjadi mitigasi. Perubahan ini dilakukan paska semakin meluasnya penyebaran virus secara global dan mulai terdeteksinya penyebaran virus secara lokal di beberapa komunitas di Taiwan. Berbeda dengan kasus SARS 2003 yang menyebar melalui penularan di rumah sakit, H1N1 menyebar melalui penularan di sekolah. Kasus H1N1 membantu Taiwan dalam menemukan kekurangan dari reformasi kebijakan pengendalian penyakit menular mereka. Dikarenakan SARS 2003 menyebar via Rumah Sakit, maka sebelum tahun 2009 Taiwan banyak berfokus untuk menghasilkan kebijakan-kebijakan terkait pengaturan penyebaran penyakit menular melalui Rumah Sakit. Dengan pengalaman H1N1 pada tahun 2009, Taiwan mulai mengeluarkan kebijakan terkait penanggulangan penularan di luar rumah sakit, terutama di sekolah. Pada tahun 2009, Taiwan mengeluarkan kebijakan penangguhan kelas tapi tidak menutup sekolah secara keseluruhan. Murid diliburkan selama lima hari saat Taiwan mendeteksi penyebaran virus lokal di komunitas masyarakat. Setelah 5 hari libur, kemudian kelas kembali dilanjutkan dengan menjalankan berbagai mekanisme terkait pencegahan penyebaran virus. Dalam hal ini, siswa dilarang 
untuk melakukan kegiatan di luar ruangan dan menghindari terjadinya kerumunan. Seluruh masyarakat diwajibkan menggunakan masker dan menjaga kebersihan diri. Kebijakan penundaan kelas ini pada akhirnya membuat sistem belajar mengajar tetap berlangsung ditengah pandemi.

Selain kebijakan penundaan kelas, kebijakan lain yang juga diterapkan adalah Community Influenza Centres (CICs). Dalam protokol penanganan penyakit menular yang disusun Taiwan, jika seandainya terdapat pandemi maka akan dibuat pos pemeriksaan di luar ruangan RS. Berhubung penyebaran H1N1 dianggap relatif lebih ringan, maka pemerintah Taiwan lebih memilih membangun Community Influen za Centres dibandingkan pos pemeriksaan demam di luar ruangan rumah sakit. Pembangunan CICs ini pada akhirnya mempermudah pengecekan kesehatan masyarakat tanpa perlu datang ke rumah sakit. Hal ini pada akhirnya membuktikan bahwa protokol yang telah dibuat dapat dimodifikasi dalam masa pandemi untuk mendapatkan hasil yang lebih efektif dan efisien.

Pandemi H1N1 lebih mudah dikendalikan oleh Taiwan dibandingkan dengan kasus SARS 2003. Tingkat mortalitas akibat virus H1N1 di Taiwan adalah 1,8 per juta, sepertiga dari rata-rata tingkat kematian di negara-negara anggota Organization for Economic Cooperation and Development (OECD). Taiwan bahkan menduduki peringkat lima besar di dunia dalam cakupan pemberian vaksin H1N1 sebesar 25\% dari total populasi (Lai, 2018). Hal ini tidak terlepas dari transformasi kebijakan yang dibuat Taiwan paska SARS 2003. Taiwan membuktikan bahwa mereka mengambil pembelajaran dari pandemi SARS 2003 dan mempersiapkan diri dengan baik untuk kemungkinan buruk penyebaran pandemi di masa datang. Kebijakan-kebijakan yang dikembangkan dari tahun 2004 hingga 2009, kemudian beberapa inovasi kebijakan saat pandemi H1N1 di tahun 2009 semakin menguatkan kesiapan negara ini dalam menghadapi pandemi-pandemi berikutnya di masa depan.

\section{COVID-19 dan Taiwan Model}

Pemerintah Taiwan mendapatkan informasi tentang adanya wabah radang paru-paru di China melalui pemberitaan di internet pada 31 Januari 2019. Taiwan langsung mengirim email ke WHO dan CDC Tiongkok menanyakan tentang kasus ini. Walaupun tidak mendapatkan tanggapan dari WHO maupun Tiongkok, pada 2 Januari 2020 Taiwan mulai memperketat aturan pelaporan kasus dan mekanisme pengendalian penyakit menular di Rumah Sakit di bawah sistem perlindungan kesehatan Taiwan. Kemudian pada 5 Januari 2020 Taiwan membentuk gugus tugas khusus untuk menangani kasus ini. Dua hari setelahnya, pada 7 Januari 2020, Taiwan mengeluarkan Level 1 travel notice untuk Wuhan. 
Seminggu setelahnya, pada 15 Januari 2020, pemerintah Taiwan mengumumkan bahwa penyakit radang paru-paru tersebut merupakan penyakit menular dan memberikan peringatan kepada seluruh institusi layanan kesehatan dan masyarakat Taiwan untuk berhatihati dan siap siaga. Menyusul pada 20 Januari, Taiwan mengaktifkan Pusat Komando Epidemi (Central Epidemic Command Center) mereka. Di hari yang sama, presiden Tsai Ing-Wen juga mengadakan pertemuan darurat Dewan Keamanan Nasional untuk mengintegrasikan dan mengkoordinasikan upaya antar kementerian dalam mengendalikan penyebaran Covid19, juga mengatur tentang bantuan keuangan dan stimulus ekonomi (John Hopkins Bloomberg School of Public Health, 2020).

Menurut wakil presiden Chen, respons cepat Taiwan terkait Covid-19 ini tidak terlepas dari pengalaman mereka dalam menanggulangi penyebaran SARS pada tahun 2003 dan virus H1N1 pada tahun 2009. Strategi yang diterapkan Taiwan di antaranya adalah: karantina perbatasan, karantina dan isolasi mandiri di rumah selama 14 hari, memobilisasi sistem perlindungan kesehatan terkait penyakit menular (National Health Insurance), menjamin ketersedian peralatan medis dan alat perlindungan diri, dan dengan cepat memberikan peringatan perjalanan. Pusat Komando Epidemi (CECC) mengadakan konferensi pers setiap hari untuk memberikan informasi yang akurat dan transparan, juga memberikan pengetahuan kesehatan dan manajemen resiko kepada publik. Pemerintah meminta masyarakat untuk menjaga jarak sosial dan menghindari kerumunan orang banyak (John Hopkins Bloomberg School of Public Health, 2020).

Kasus Covid-19 pertama di Taiwan dikonfirmasi pada tanggal 21 Januari 2020. Puncak pertama penyebaran Covid-19 terjadi di bulan Januari dimana mayoritas kasus merupakan impor dari China. Puncak penyebaran kedua terjadi pada pertengahan Maret dengan mayoritas kasus merupakan impor dari Eropa dan Amerika Serikat. Setelah dikonfirmasinya kasus positif pertama, Taiwan langsung mengeluarkan peringatan perjalanan tingkat 3 (travel notice of Level 3) untuk Wuhan dimana penerbangan dari dan menuju Wuhan dibatalkan untuk sementara waktu. Kemudian saat puncak penyebaran kedua, pada 21 Maret Taiwan kembali mengeluarkan peringatan perjalanan untuk seluruh negara di dunia. Larangan kunjungan sementara ke Taiwan dikeluarkan pada 6 Februari untuk warga negara Tiongkok, 11 Februari untuk warga negara Hongkong dan Makau, hingga akhirnya larangan kunjungan ke Taiwan bagi seluruh masyarakat internasional dikeluarkan pada 19 Maret (John Hopkins Bloomberg School of Public Health, 2020). 
Taiwan memberlakukan berbagai aturan karantina bagi pendatang yang memasuki wilayah Taiwan, di antaranya: melakukan pengecekan kesehatan dan pemesanan hotel karantina sebelum pengunjung menaiki pesawat menuju ke Taiwan, pengumuman dan karantina selama penerbangan, pemberitahuan melalui telepon tentang karantina rumah selama 14 hari setelah kedatangan, pemeriksaan di bandara dan di rumah, memastikan transporasi lokal yang aman, serta mengawasi karantina mandiri pendatang baik di rumah maupun di hotel. Pendatang wajib mematuhi aturan karantina mandiri selama 14 hari di rumah. Aturan ini juga diberlakukan bagi orang-orang yang memiliki kontak dengan pasien yang dikonfirmasi positif terjangkit Covid-19. Pegawai pemerintah maupun petugas kesehatan akan memonitor orang-orang yang menjalani karantina satu atau dua kali dalam sehari (John Hopkins Bloomberg School of Public Health, 2020).

Salah satu inovasi Taiwan dalam pengendalian penyebaran Covid-19 adalah dengan memanfaatkan perkembangan Teknologi Informasi, seperti yang teah diterapkan dan dikembangkan sejak kasus SARS tahun 2003. Taiwan menggunakan sistem pemantauan keamanan elektronik untuk memeriksa kesehatan setiap masyarakat, wilayah, juga orangorang yang menjalani karantina rumah maupun isolasi. Masyarakat diminta untuk mengisi informasi tentang TOCC (riwayat perjalanan, pekerjaan, riwayat kontak, informasi klaster wilayah) mereka secara online. Sistem pelacakan karantina rumah digunakan untuk meberikan layanan dan dukungan untuk orang-orang yang dikarantina. Aplikasi LINE digunakan untuk pelaporan status kesehatan, permintaan konsultasi medis, dan layanan perawatan kesehatan. Taiwan juga menggunakan sistem pelacakan digital untuk memperingatkan orang-orang yang dikarantina jika mereka keluar dari wilayah karantina yang telah ditentukan. Pemerintah daerah juga menyediakan berbagai layanan dan dukungan untuk orang-orang yang dikarantina dan isolasi seperti: layanan konsultasi tak berbatas waktu, kunjungan keluarga, pengiriman makanan, pengumpulan sampah, dan pengaturan layanan kesehatan. Orang yang memiliki gejala Covid-19 dijemput menggunakan ambulan, sedangkan yang tidak mempunyai gejala akan didukung dengan layanan kesehatan yang dibutuhkan (John Hopkins Bloomberg School of Public Health, 2020).

Pada 1 April 2020, CECC Taiwan mengumumkan aturan terkait pengaturan jarak sosial. Masyarakat diminta menjaga jarak minimal 1.5meter saat di dalam ruangan dan 1 meter saat di luar ruangan. Masyarakat diminta untuk mengunakan masker di area keramaian, juga membatasi kunjungan ke kuil, taman nasional, hotel, pasar malam, dan area perbelanjaan. Masyarakat Taiwan sangat patuh terhadap himbauan ini. Mereka mempraktekkan jarak sosial 
dengan baik baik itu di transportasi umum, restoran, sekolah, maupun tempat umum lainnya (John Hopkins Bloomberg School of Public Health, 2020).

Pemerintah Taiwan membentuk tim masker nasional untuk mengembangkan 92 lini produksi dan melibatkan 73 perusahaan lainnya untuk memproduksi masker. Terhitung hingga 16 April rata-rata produksi masker naik dari 1.9 juta di awal Januari menjadi 16 juta di pertengahan April. Kenaikan produksi ini disokong oleh kebijakan mengenai integrasi bahan baku, mesin, lini produksi, dan catu daya yang stabil. Masyarakat bisa membeli masker di apotek dengan menggunakan kartu asuransi nasional. Pemerintah juga menyediakan website untuk membeli masker secara online, lalu membayarnya dengan ATM atau kartu kredit, dan kemudian mengambilnya di toko serba ada (convenience store) (John Hopkins Bloomberg School of Public Health, 2020).

Hingga Desember 2020, kasus terkonfirmasi COVID-19 di Taiwan berada di bawah 1000. Selama beberapa bulan berturut-turut Taiwan mengalami kasus nihil di saat penyebaran virus ini masih berkembang pesat di seluruh dunia. Taiwan adalah salah satu negara dengan penyebaran lokal paling rendah karena kasus terkonfirmasi positif lebih banyak merupakan kasus impor (pasien merupakan pendatang dari luar negeri). Taiwan juga tidak pernah melakukan lockdown selama masa pandemi Covid-19. Melihat kedekatan wilayah juga intensitas hubungan antara Tiongkok dan Taiwan yang cukup tinggi, rendahnya kasus terkonfirmasi dan tidak adanya lockdown ini membuktikan bahwa Taiwan siap dan sigap dalam menangani penyebaran COVID-19. Pembelajaran yang diambil Taiwan dari pandemi SARS 2003 dan H1N1 telah mengantarkan negara ini sebagai salah satu negara yang sukses melindungi masyarakatnya dari pandemi COVID-19.

\section{Pembelajaran Bagi Negara Berkembang}

Menurut wakil presiden Chen saat menjadi pembicara dalam webinar yang diselenggarakan oleh Universitas Jhon Hopkins, terdapat 8 pembelajaran yang bisa diambil dari respons Taiwan dalam menghadapi pandemi yaitu: Pertama, perlu adanya upaya pemantauan terus menerus terhadap penyakit menular yang muncul dari berbagai wilayah di dunia, terutama di negara-negara berpenduduk banyak seperti China. Hal ini bisa dilakukan dengan memanfaatkan informasi dari berbagai sumber, apalagi dengan perkembangan internet yang memungkinkan informasi bisa menyebar dengan cepat; Kedua, optimalisasi karantina perbatasan. Saat sudah mulai ada indikasi penyebaran penyakit di sebuah wilayah, maka pemerintah harus segera mengoptimalkan upaya karantina perbatasan untuk meminimalisir impor kasus dari negara lain; Ketiga, memperkuat pelaporan penyakit 
menular melalui sistem kesehatan nasional; Keempat, kombinasi perencanaan respons terhadap kemunculan penyakit menular dan pelacakan persebaran kontak penyebaran; Kelima, meningkatkan kemampuan laboratorium agar bisa dengan cepat melakukan deteksi dan diagnosis awal; Keenam, pendidikan kesehatan publik yang komprehensif melalui institusi pendidikan maupun secara umum kepada masyarakat; Ketujuh, penyampaian informasi mengenai wabah secara terbuka dan transparan; Kedelapan, kolaborasi internasional dalam upaya penanggulangan wabah, juga dalam penelitian dan pengembangan vaksin.

Penjelasan Wakil Presiden Chen di atas merupakan akumulasi dari pengalaman Taiwan setelah tiga kali mengalami pandemi dan transformasi kebijakan mereka di setiap pandemi. Hal ini bisa kita lihat lebih lanjut dalam tabel dibawah ini:

Tabel 1. Perbandingan Respons Taiwan dalam Menghadapi Pandemi

\begin{tabular}{|c|c|c|c|}
\hline Respons & SARS 2003 & H1N1 2009 & COVID-19 \\
\hline Pemantauan & $\begin{array}{l}\text { Pemerintah belum } \\
\text { sepenuhnya } \\
\text { melakukan } \\
\text { pemantauan } \\
\text { terhadap } \\
\text { penyebaran virus }\end{array}$ & $\begin{array}{l}\text { Pemantauan dilakukan } \\
\text { setelah WHO } \\
\text { mengumumkan potensi } \\
\text { penyebaran virus secara } \\
\text { global }\end{array}$ & $\begin{array}{l}\text { Pemantauan } \\
\text { dilakukan bahkan } \\
\text { sebelum WHO } \\
\text { mengumumkan } \\
\text { pandemi }\end{array}$ \\
\hline $\begin{array}{l}\text { Karantina } \\
\text { Perbatasan }\end{array}$ & $\begin{array}{l}\text { Longgar dalam } \\
\text { melakukan } \\
\text { karantina } \\
\text { perbatasan }\end{array}$ & $\begin{array}{l}\text { Karantina perbatasan } \\
\text { mulai diperketat saat } \\
\text { pandemi berkembang } \\
\text { secara global }\end{array}$ & $\begin{array}{l}\text { Karantina } \\
\text { perbatasan sangat } \\
\text { ketat bahkan } \\
\text { sebelum pandemi } \\
\text { berkembang secara } \\
\text { global }\end{array}$ \\
\hline $\begin{array}{l}\text { Pelaporan } \\
\text { penyakit } \\
\text { menular }\end{array}$ & $\begin{array}{l}\text { Awalnya } \\
\text { mengandalkan } \\
\text { pelaporan manual } \\
\text { oleh dokter } \\
\text { kemudian mulai } \\
\text { komputerisasi }\end{array}$ & $\begin{array}{l}\text { Pelaporan sudah } \\
\text { terkomputerisasi }\end{array}$ & $\begin{array}{l}\text { Pelaporan yang } \\
\text { telah } \\
\text { terkomputerasi } \\
\text { diperkuat dengan } \\
\text { Artificial Intelligence } \\
\text { (AI) dan analisis big } \\
\text { data }\end{array}$ \\
\hline
\end{tabular}




\begin{tabular}{|c|c|c|c|}
\hline $\begin{array}{l}\text { Perencanaan } \\
\text { respons }\end{array}$ & $\begin{array}{l}\text { Respons bersifat } \\
\text { sporadis, tidak } \\
\text { terarah, dan kurang } \\
\text { koordinasi }\end{array}$ & $\begin{array}{l}\text { Respons lebih terarah, } \\
\text { koordinasi antar agensi } \\
\text { berjalan lancar }\end{array}$ & $\begin{array}{l}\text { Respons sangat } \\
\text { terarah, koordinasi } \\
\text { antar agensi telah } \\
\text { dilakukan sebelum } \\
\text { adanya kasus } \\
\text { terkonfirmasi, } \\
\text { pemeintah cepat } \\
\text { tanggap dalam } \\
\text { mengambil } \\
\text { keputusan } \\
\text { pencegahan }\end{array}$ \\
\hline $\begin{array}{l}\text { Pelacakan } \\
\text { kontak } \\
\text { penyebaran }\end{array}$ & $\begin{array}{l}\text { Pelacakan sulit } \\
\text { dilakukan }\end{array}$ & $\begin{array}{l}\text { Pelacakan lebih mudah } \\
\text { dilakukan karena } \\
\text { koordinasi antar agensi } \\
\text { telah berjalan lancar dan } \\
\text { pelaporan kasus } \\
\text { terdokumentasi dengan } \\
\text { baik }\end{array}$ & $\begin{array}{l}\text { Pelacakan dilakukan } \\
\text { dengan mudah } \\
\text { karena adanya } \\
\text { koordinasi yang } \\
\text { baik antar agensi, } \\
\text { juga dengan } \\
\text { memanfaatkan } \\
\text { kemajuan IT seperti } \\
\text { AI dan analisis big } \\
\text { data }\end{array}$ \\
\hline $\begin{array}{l}\text { Kesiapan } \\
\text { Laboratorium }\end{array}$ & $\begin{array}{l}\text { Laboratorium siap } \\
\text { tetapi hanya untuk } \\
\text { kasus kecil }\end{array}$ & $\begin{array}{l}\text { Reformasi kebijakan } \\
\text { publik yang telah } \\
\text { dilakukan pemerintah } \\
\text { memungkinkan untuk } \\
\text { melakukan deteksi dan } \\
\text { diagnosis awal dengan } \\
\text { cepat }\end{array}$ & $\begin{array}{l}\text { Reformasi kebijakan } \\
\text { publik yang telah } \\
\text { dilakukan } \\
\text { pemerintah } \\
\text { memungkinkan } \\
\text { untuk melakukan } \\
\text { deteksi dan } \\
\text { diagnosis awal } \\
\text { dengan cepat }\end{array}$ \\
\hline $\begin{array}{l}\text { Pendidikan } \\
\text { Kesehatan } \\
\text { Publik }\end{array}$ & $\begin{array}{l}\text { Kesadaran publik } \\
\text { tentang bahaya }\end{array}$ & $\begin{array}{l}\text { Masyarakat sangat } \\
\text { waspada dengan penyakit } \\
\text { menular }\end{array}$ & $\begin{array}{l}\text { Masyarakat sangat } \\
\text { waspada dengan } \\
\text { penyakit menular }\end{array}$ \\
\hline
\end{tabular}




\begin{tabular}{|l|l|l|l|}
\hline & $\begin{array}{l}\text { penyakit menular } \\
\text { masih kurang }\end{array}$ & & $\begin{array}{l}\text { dan telah terlatih } \\
\text { dengan baik untuk } \\
\text { menggunakan } \\
\text { masker }\end{array}$ \\
\hline $\begin{array}{l}\text { Penyampaian } \\
\text { informasi }\end{array}$ & $\begin{array}{l}\text { Informasi masih } \\
\text { dipolitisasi, tidak } \\
\text { transparan, tidak } \\
\text { terkoordinasi, dan } \\
\text { meresahkan } \\
\text { masyarakat }\end{array}$ & Informasi disampaikan & $\begin{array}{l}\text { Informasi } \\
\text { disampaikan secara } \\
\text { transparan dan }\end{array}$ \\
& & $\begin{array}{l}\text { terkendali } \\
\text { terkendali, juga } \\
\text { melakukan inovasi } \\
\text { dengan } \\
\text { memanfaatkan } \\
\text { berbagai media } \\
\text { penyampaian dan }\end{array}$ \\
& & $\begin{array}{l}\text { penangkalan } \\
\text { informasi hoaks }\end{array}$ \\
\hline
\end{tabular}

Sumber: diolah penulis dari berbagai sumber

Pada saat SARS 2003, pengetahuan dan infomasi yang dimiliki Taiwan terkait penyebaran penyakit menular masih sangat terbatas. Dalam satu dekade sebelum pandemi SARS, Taiwan belum mengalami pengalaman dalam penyebaran penyakit menular secara global. Hal ini pada akhirnya membuat pemerintah dan masyarakat lengah dan cenderung menyepelekan kebijakan publik terkait pandemi. Lebih lanjut, Rumah Sakit menjadi pusat episentrum penyebaran pandemi karena tidak adanya regulasi pengontrolan penyakit menular yang jelas. Hal ini diperparah dengan tidak transparannya pelaporan dan penanganan wabah. Sikap "menolak kenyataan" dan upaya "menyelamatkan muka" yang dilakukan oleh pihak Rumah Sakit malah menjadi bom waktu yang akhirnya memperluas penyebaran penyakit dan menyebabkan banyaknya korban dan kerugian (Chen, 2005). Pembelajaran yang diambil Taiwan dari permasalahan ini adalah tentang kurangnya regulasi sehingga penanganan permasalahan bersifat sporadis dan tidak memiliki petunjuk serta diperparah dengan tidak adanya kekuatan hukum yang mengikat (Ho, 2004). Paska SARS 2003, Taiwan fokus membangun regulasi dan melakukan transformasi kebijakan. Kebijakan publik terkait pengendalian penyakit menular menjadi salah satu fokus utama pemerintah Taiwan dan hal ini juga sepatutnya dilakukan oleh negara berkembang di masa depan. Peyebaran Covid-19 yang menghantam dan melumpuhkan dunia pada tahun 2020 mutlak harus dijadikan 
pembelajaran bagi seluruh negara terutama negara berkembang untuk memprioritaskan kebijakan publik terkait pengendalian penyakit menular. Upaya-upaya pencegahan akan jauh lebih efektif dan efisien dibandingkan dengan upaya represif.

Kebijakan kesehatan publik lainnya yang juga perlu untuk dipertimbangkan adalah terkait perlindungan sosial. Taiwan telah menerapkan kebijakan perlindungan sosial satu pintu dimana pemerintah berperan sebagai regulator dan swasta berperan sebagai penyedia layanan. Kombinasi kerja sama yang baik antara pemerintah dan swasta telah mengantarkan asuransi kesehatan Taiwan sebagai asuransi kesehatan paling efisien dan terbaik di dunia (Putri, 2020). Regulasi dan peran aktif pemerintah dalam perlindungan kesehatan menunjukkan kehadiran negara untuk masyarakatnya dan di saat yang bersamaan tetap menjaga sistem perekonomian pasar untuk menjaga kualitas layanan. Sebagai salah satu kebutuhan masyarakat, kesehatan sangat memerlukan intervensi pemerintah, baik itu dalam penyediaan layanan maupun upaya untuk mengembangkan infrastruktur kesehatan serta dukungan data dan kebijakan berbasis IT.

Lebih lanjut, sesuai dengan yang dikatakan oleh Direktur Jenderal WHO, Thedros Adhanom, kepemimpinan yang kuat adalah salah satu kunci sukses dalam penanganan pandemi. Pemimpin negara dan unit-unit dibawahnya memerlukan koordinasi yang baik agar bisa mengendalikan pandemi dengan baik. Para pemimpin negara wajib mengambil alih kendali keadaan darurat dan berkomunikasi secara efektif dengan penduduk mereka tentang tindakan yang harus diambil. Kepimpinan yang kuat memungkinkan untuk membangun kepercayaan antara pemimpin negara dan masyarakatnya sehingga langkah-langkah pengendalian bisa dilakukan dengan efektif. Hal ini dapat dilakukan melalui kepemimpinan pemerintah yang kuat dan koordinasi strategi komprehensif yang dikomunikasikan dengan jelas dan konsisten. Menerapkan dasar-dasarnya dan bekerja dengan tokoh masyarakat dan semua pemangku kepentingan untuk menyampaikan pesan kesehatan masyarakat yang jelas (VOA, 2020).

Hal yang tidak bisa dilepaskan dalam penanganan pandemi ini adalah tentang pendidikan kesehatan publik dan itu memerlukan waktu yang panjang. Membangun kesadaran publik terkait pandemi memerlukan keterlibatan berbagai pihak termasuk institusi pendidikan dan keluarga. Negara perlu untuk selalu mengkampanyekan hidup sehat baik saat pandemi maupun tidak. Selain itu, perlu meningkatkan kesadaran masyarakat tentang penyakit menular agar kewaspadaan masyarakat jauh lebih tinggi saat menghadapi pandemi. Untuk meningkatkan kesadaran ini, aktor negara memerlukan dukungan aktor non-negara 
atau yang sering disebut dengan masyarakat sipil. Menginisiasi kegiatan-kegiatan terkait diseminasi informasi mutlak diperlukan agar kesadaran hidup bersih dan waspada terhadap penyakit menular menjadi sebuah kebudayaan dan kebiasaan di tengah-tengah masyarakat (Yen, 2014).

Terakhir adalah dalam persebaran informasi terkait pandemi. Pada saat SARS 2003, Taiwan menghadapi masa-masa sulit salah satunya disebabkan oleh penyebaran berita yang tidak terkendali dan menyebabkan kepanikan di tengah masyarakat. Untuk keluar dari kondisi tersebut, pemerintah menginisiasi pusat informasi yang menjadi sumber rujukan utama tentang pemberitaan terkait pandemi. Hal ini pada akhirnya sedikit demi sedikit mampu menenangkan masyarakat dan penyebaran informasi juga bisa dikendalikan (Su, 2008). Saat merebaknya kasus H1N1, Taiwan kembali menggunakan sistem ini lebih awal untuk memastikan masyarakat mendapatkan informasi yang akurat dan terbukti mampu mengendalikan informasi dan mencegah kepanikan ditengah masyarakat. Pengendalian penyebaran informasi ini jauh lebih maju pada saat pengendalaian penyebaran COVID-19 dimana pemerintah tidak hanya mengaktifkan pusat informasi satu pintu yang selalu memberikan informasi terbaru tiap harinya tapi pemerintah juga secara proaktif mengatasi berita hoaks dengan memanfaatkan kemajuan IT dan analisis big data. Pemerintah juga menyediakan media sumber informasi bervariasi baik itu melalui situs web, media sosial, radio, televisi, dan media lainnya (John Hopkins Bloomberg School of Public Health, 2020). Pengendalian pemberitaan ini mutlak dilakukan oleh negara saat menghadapi pandemi dan akan lebih baik dilakukan lebih awal sebelum kasus terkonfirmasi seperti yang dilakukan Taiwan pada pandemi Covid-19.

\section{KESIMPULAN}

Tulisan ini telah memberikan gambaran tentang transformasi kebijakan Taiwan terkait pengendalian penyebaran penyakit menular. Lebih jauh, tulisan ini juga telah memberikan uraian tentang poin-poin penting yang dapat dipelajari oleh negara berkembang dari pengalaman Taiwan tersebut. Tulisan ini menyimpulkan bahwa peran aktif pemerintah untuk mendorong reformasi kebijakan kesehatan publik mutlak diperlukan. Jika memungkinkan, Undang-Undang terkait hal ini perlu untuk dibuat. Selain pembuatan aturan, hal lain yang tak kalah penting adalah kontrol pemerintah baik saat terjadi pandemi, paska pandemi, maupun kewaspadaan menghadapi pandemi lain di masa depan. Melihat perbandingan respons Taiwan di saat pandemi mengajarkan kita bahwa perlu adanya transformasi kebijakan secara terus menerus untuk menanggulangi permasalahan penyakit 
menular. Bagi negara-negara yang saat ini kewalahan menghadapi pandemi, dari Taiwan kita belajar bahwa efek buruk dan kegagalan dalam mengendalikan penyebaran penyakit menular dapat dijadikan pembelajaran di masa depan untuk melakukan transformasi kebijakan dan bisa lebih siap dan sigap di masa pandemi mendatang.

\section{DAFTAR PUSTAKA}

Chen, K.-T. T.-J.-L.-C.-T.-H.-J. SARS in Taiwan: An Overview and Lessons Learned. International Journal of Infectious Diseases 2005, 9: 77-85.

Cheng, H.-Y. L.-Y.-H. Initial Rapid and Proactive Response for the COVID-19 Outbreak Taiwan's Experience. Journal of the Formosan Medical Association 2020, 119: 771-773.

Cheng, S.-C. C.-C.-L.-C.-H.-H.-N. First Case of Corona Virus Disease 2019 (COVID-19)

Pneumonia in Taiwan. Journal of the Formosan Medical Association 2020, 119: 747-751.

Cyranoski, D. Taiwan left isolated in fight against SARS. Nature 2003, 422-652.

Hahow. The Coronavirus: A Crash Course by Taiwan Vice President Chen Chien-Jen (Multi-language Version) (2020, April 30). Diakses dari https://www.youtube.com/watch?v=tI3KJLRKkE0

Ho, M.-S. S.-J. Preparing to Prevent Severe Acute Respiratory Syndrome and Other Respiratory Infections. Lancet Infectious Disease 2004, 684-689.

John Hopkins Bloomberg School of Public Health. Inside Taiwan's Response to COVID-19. (2020, April 25). Diakses dari https://www.youtube.com/watch?v=ReI6ROZNbkk

John Hopkins Bloomberg School of Public Health. Transcript Webinar with Vice President Chen 2020, diakses dari https://www.jhsph.edu/covid-19/news-andevents/events/_documents/2020-04-24-inside-taiwanas-response-to-covid-19transcript.pdf

Lai, A. Y.-H. Agility Amid Uncertainties: Evidence from 2009 A/H1N1 Pandemics in Singapore and Taiwan. Policy and Society 2018, 37(4), 459-472.

Lee, I.-K. W.-C.-C.-T.-C.-T. Letter to the Editor Effective Strategies to Prevent Coronavirus Disease-2019 (COVID-19) Outbreak in Hospital. Jurnal of Hospital Infection 2020, 105, 102-103.

Lin, C.-Y., Cheng, C.-H., Lu, P.-L, Shih, D.-C, Hung, C.-T, Lo, H.-H., Tsai, M.-J., Hung, J.Y. Active Surveillance for Suspected COVID-19 Cases in Inpatients with Information Technology. Journal of Hospital Infection 2020, 105: 197-199.

Lin, C., Braund, W. E., Auerbach, J., Chou, J.-H., Teng, J.-H., Tu, P., \& Mullen, J. Policy Decisions and Use of Information Technology to Fight COVID-19. (2020, July). Diakses dari: Taiwan Centers for Disease Control: www.cdc.gov/eid 
$\mathrm{Pu}, \mathrm{V}$. The Coronavirus Outbreak: How Democratic Taiwan Outperformed Authoritarian China. (2020, February). Diakses dari https://thediplomat.com/2020/02/thecoronavirus-outbreak-how-democratic-taiwan-outperformed-authoritarian-china/

Putri, A., Silvia, D., Rika, I., Rezya, A. Kebijakan Asuransi Kesehatan Taiwan (Taiwan National Health Insurance) dan Pembelajaran Bagi Negara Berkembang. Jurnal Kebijakan Kesehatan Indonesia 2020, 9, 3, 167-177

Schlein, Lisa. WHO: Strong Leadership, Community Compliance Can Crush COVID-19. Diakses dari https://www.voanews.com/covid-19-pandemic/who-strongleadership-community-compliance-can-crush-covid-19

Severe Acute Respiratory Syndrome, Taiwan. (2003). Diakses dari: https://www.cdc.gov/mmwr/preview/mmwrhtml/mm5220a1.htm

Simon Institute. The Digital Fence: Taiwan's Response to COVID-19: (2020, April 7). Diakses melalui https://www.youtube.com/watch?v=ScIVe6STVxI

Taiwan Ministry of Foreign Affairs. Open and Transparent Information Promoting Social Stability. (2020, May). Diakses dari

https://www.mofa.gov.tw/Upload/RelFile/2890/172265/20200517_1$6 \% 20$ Open $\% 20$ and $\% 20$ transparent $\% 20$ Information $\% 20 \% 20$.pdf

Taiwan Ministry of Foreign Affairs. Public-private partnerships to contain COVID-19. (2020, May). Diakses dari:

https://www.mofa.gov.tw/Upload/RelFile/2890/172267/20200517_14\%20Public $\% 20$-private $\% 20$ partnerships.pdf

Taiwan Ministry of Foreign Affairs. Tackling COVID-19 with the help of big data and AI. (2020, May). Diakses dari:

https://www.mofa.gov.tw/Upload/RelFile/2890/172266/20200517_15\%20Tackling $\% 20$ COVID-

19\%20with $\% 20$ the $\% 20$ help $\% 20$ of $\% 20$ big $\% 20$ data $\% 20 \%$ e $7 \% 89 \% 88 \%$ e6 $\% 9$ c $\%$ ac )$\cdot \mathrm{pdf}$

Taiwan Ministry of Foreign Affairs. Advance preparations and early response to COVID-19 pandemic. (2020, May). Diakses dari: https://www.mofa.gov.tw/Upload/RelFile/2890/172268/20200517_1$3 \% 20$ Advance $\% 20$ preparations $\% 20$ and $\% 20$ early $\% 20$ response.pdf

Taiwan Ministry of Foreign Affairs. Taiwan's comprehensive national health insurance system and our experience of fighting the SARS epidemic. (2020, May). Diakses dari: https://www.mofa.gov.tw/Upload/RelFile/2890/172272/20200517_11Taiwan's $\% 20$ comprehensive $\% 20$ national $\% 20$ health $\% 20$ insurance $\% 20$ system.pdf 
Taiwan MInistry of Foreign Affairs. A Whole-of-Government System Coordinating Interagency Resources and Manpower-doing Battle Against COVID-19 through Unified, Decisive Efforts. (2020, May). Diakses dari:

https://www.mofa.gov.tw/Upload/RelFile/2890/172271/20200517_1-2\%20A\%20wholeof-governement $\% 20$ systme.pdf

Tsung-Shu Joseph Wu, F.-Y. F.-Y.-S.-W.-M.-H.-T.-H.-C.-J.-C. Establishing a Nationwide Emergency Department-Based Syndromic Surveillance System for Better Public Health Responses in Taiwan. BMC Public Health 2008, 8(18).

Twu, S.-J. C.-J.-J.-T.-H.-C.-T.-H.-C.-S. Control Measures for Severe Acute Resporatory Syndrome (SARS) in Taiwan. Emerging Infectious Diseases 2003, 9(6).

Wang, C. J., Ng, C. Y., \& Brook, R. H. Response to COVID-19 in Taiwan Big Data Analytics, New Technology, and Proactive Testing. The Journal of the American Medical Association 2020, 323(14), 1341-1342.

Yang, C.-J., Chen, T.-C., Chen, Y.-H. The Preventive Strategies of Community Hospital in the Battle of Fighting Pandemic COVID-19 in Taiwan. Journal of Microbiology, Immunology and Infection 2020, 53: 381-383.

Yen, M.-Y. C.-H.-C.-E.-C.-R. From SARS in 2003 to H1N1 in 2009: Lessons Learned from Taiwan in Preparation for the Next Pandemic. Journal of Hospital Infection 2014, 87: 185-193. 